This item was submitted to Loughborough's Research Repository by the author.

Items in Figshare are protected by copyright, with all rights reserved, unless otherwise indicated.

\title{
Sintering behaviour of Al-Cu-Mg-Si blends
}

PLEASE CITE THE PUBLISHED VERSION

http://www.scientific.net

PUBLISHER

(c) Trans Tech Publications

VERSION

AM (Accepted Manuscript)

LICENCE

CC BY-NC-ND 4.0

REPOSITORY RECORD

Falticeanu, C.L., Isaac T. Chang, Jung-Sik Kim, and R. Cook. 2012. "Sintering Behaviour of Al-cu-mg-si Blends". figshare. https://hdl.handle.net/2134/11228. 
This item was submitted to Loughborough's Institutional Repository (https://dspace.lboro.ac.uk/) by the author and is made available under the following Creative Commons Licence conditions.

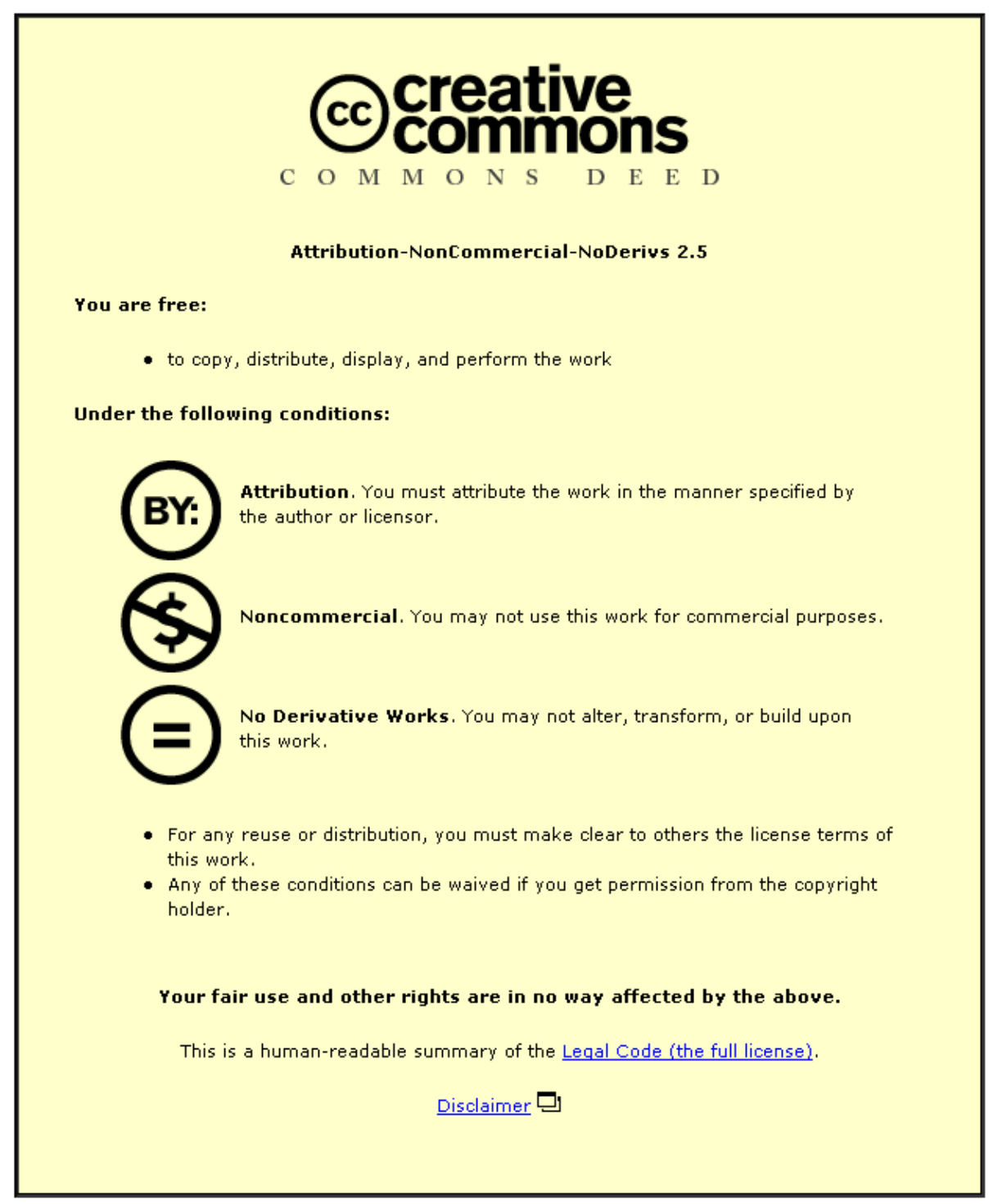

For the full text of this licence, please go to: http://creativecommons.org/licenses/by-nc-nd/2.5/ 


\title{
Sintering behaviour of Al-Cu-Mg-Si blends
}

\author{
C.L Falticeanu ${ }^{1, \mathrm{a}}$, I.T.H Chang ${ }^{1, \mathrm{~b}}$,J.S. Kim ${ }^{2, \mathrm{c}}$, R. Cook $^{3, \mathrm{~d}}$ \\ ${ }^{1}$ Department of Metallurgy and Materials, University of Birmingham, Edgbaston, Birmingham, B15 2TT, \\ United Kingdom \\ ${ }^{2}$ Department of Mechanical and Manufacturing Engineering, University of Birmingham, Edgbaston, \\ Birmingham, B15 2TT, United Kingdom
}

${ }^{3}$ The Aluminium Powder Company Limited, Forge Lane, Minworth, Sutton Coldfield, B76 1AH, United Kingdom

alucianfalticeanu@yahoo.co.uk, bi.t.chang@bham.ac.uk, ${ }^{c}$ jsk238@bham.ac.uk, ${ }^{d}$ rcook@alpoco.co.uk

Keywords: Sintering, Aluminium alloy, microstructure and differential thermal analysis.

\begin{abstract}
The increasing demand for automotive industries to reduce the weight of the vehicles has led to a growing usage of $\mathrm{Al}$ alloy powder metallurgy $(\mathrm{P} / \mathrm{M})$ parts such as camshaft bearing caps, shock absorber pistons and brake calipers [1,2]. In order to control the sintered microstructure and mechanical properties of the aluminium alloy powder metallurgical $(\mathrm{P} / \mathrm{M})$ parts, it is essential to establish a fundamental understanding of the microstructural development during the sintering process. Current research at Birmingham University is focussed on the investigation of the sintering behaviour of Al-Cu-Mg-Si powder blends using a combination of Scanning Electron Microscopy, Energy Dispersive Microanaylsis (SEM) and Differential Scanning Calorimetry (DSC). This paper presents a detailed study of the effect of temperature and initial starting materials on the evolution of microstructure during the sintering of $\mathrm{Al}-\mathrm{Cu}-\mathrm{Mg}-\mathrm{Si}$ blends for PM.
\end{abstract}

\section{Introduction}

The demand for $\mathrm{Al}$ powders for $\mathrm{P} / \mathrm{M}$ products in North America has increased by $15 \%$ per year to 1353 tonnes in 1999 [3, 5]. These Al P/M products are primarily based on blended powder mixtures. Several P/M aluminium alloys are available for commercial use. The most commonly used for automotive components is $2 \mathrm{xxx}$ series, especially 2014 grade. This alloy is the P/M equivalent to the wrought AA2014 alloy. However, the P/M 2014 alloy contains Si addition for improved wear properties [6] and enhanced liquid phase sintering behaviour [7]. Liquid phase sintering of Al alloy is currently the only accepted technique that is capable of producing $\mathrm{P} / \mathrm{M}$ components with acceptable mechanical properties[8,9]. The liquid phase sinteraids usually are made up of either low melting point elemental additions such as $\mathrm{Sn}, \mathrm{Zn}, \mathrm{Pb}$, etc or a low melting point eutectic phase such as $\mathrm{Al}-12 \% \mathrm{Si}$ master alloy. The presence of a liquid phase not only enhances the atomic interdiffusion but also helps to break up the oxide layer on the powder. However, the disadvantage of liquid phase sintering of $\mathrm{Al}$ alloy is that distortion within the $\mathrm{P} / \mathrm{M}$ part and a reduction in mechanical properties due to the formation of a brittle intergranular phase can occur.

Current research is focussed on the optimisation of sintering conditions to improve the mechanical properties of aluminium $\mathrm{P} / \mathrm{M}$ components[7,10]. Schaffer et al.[11,12,13] demonstrated the benefficial effect of $\mathrm{Sn}$ as a sinteraid in the liquid phase sintering of Al alloy powders [14].

They observed that trace addition of elemental Sn to the blended powder can enhance the liquid phase of Al-Cu alloys by diffusing into the $\mathrm{Al}$ matrix ahead of $\mathrm{Cu}$ and thus decreasing the transient aspect of the cycle. However, there is a limited amount of data available in the literature about microstructural developments undergone by different aluminium blends during sintering. 
This paper presents a detailed study of the phase transformation occurring during the sintering of $\mathrm{Al}-\mathrm{Cu}-\mathrm{Mg}-\mathrm{Si}$ blended powder mixtures as a function of initial starting particulate constituents and sintering temperature using a combination of differential scanning calorimetry (DSC) and scanning electron microscopy (SEM).

\section{Experimental}

Two types of aluminium blends namely EleMix and AlloyMix provided by The Aluminium Powder Company Limited (Alpoco) were studied. EleMix is a blend of gas atomised elemental Al powders with elemental $\mathrm{Mg}$ and $\mathrm{Cu}$ powders and $\mathrm{Al}-12 \mathrm{wt} \% \mathrm{Si}$ master alloy powder. AlloyMix is a blend of gas atomised elemental $\mathrm{Al}$ powders with additions of $\mathrm{Al}-50 \mathrm{wt} \% \mathrm{Mg}, \mathrm{Al}-54 \mathrm{wt} \% \mathrm{Cu}$ and $\mathrm{Al}-12 \mathrm{wt} \% \mathrm{Si}$ master alloy powders. The gas atomised elemental Al powders used in EleMix and AlloyMix have the same size distribution $(+45-150 \mu \mathrm{m})$ that was optmised for maximum flow properties [16]. The overall chemical composition of both blends was the same Al-4.4\% Cu- $0.5 \% \mathrm{Mg}-0.6 \% \mathrm{Si}$. Both EleMix and AlloyMix powder mixtures were blended in a Turbula mixer operating at $50 \mathrm{rpm}$ and 25 mins.

The blended powders were compacted into discs of $5 \mathrm{~mm}$ in diameter and $10 \mathrm{~mm}$ thick using a pressure of 20tsi. The die wall was lubricated with Accrawax to ease removal of the compacted samples. Sintering of compacts were carried out in a horizontal tube furnace with a dynamic flow of nitrogen to maintain a dew point of $-45^{\circ} \mathrm{C}$. The compacts were heated at a rate of $10{ }^{\circ} \mathrm{C} / \mathrm{min}$ to a range of temperatures of $475{ }^{\circ} \mathrm{C}, 510^{\circ} \mathrm{C}, 540{ }^{\circ} \mathrm{C}$ and $600{ }^{\circ} \mathrm{C}$ for a fixed time of $10 \mathrm{mins}$, before the microstructures of the sintered components were frozen by quenching them in a pool of liquid nitrogen. The quenched samples were then mounted in cold mount resin and polished for subsequent SEM studies. Microstructure and chemical composition were studied using a Jeol 6060 SEM coupled to an Oxford Instruments Energy Dispersive Analyser.

Phase transformations during the heating of blended powders of blended EleMix and AlloyMix were studied using a Netzch Jupiter DSC operating with a dynamic flow of nitrogen, a heating rate of 10 ${ }^{\circ} \mathrm{C} /$ min over a temperature range between $200^{\circ} \mathrm{C}$ and $700^{\circ} \mathrm{C}$. In addition the reactions between binary mixtures of $\mathrm{Al}-4.4 \% \mathrm{Cu}, \mathrm{Al}-0.6 \% \mathrm{Si}$ and $\mathrm{Al}-0.5 \% \mathrm{Mg}$ prepared by either mixing $\mathrm{Al}$ powder with elemental $\mathrm{Cu}$ and $\mathrm{Mg}$ powders or master alloys powder (eg. $\mathrm{Al}-50 \% \mathrm{Mg}, \mathrm{Al}-50 \% \mathrm{Cu}$ and $\mathrm{Al}-$ $12 \% \mathrm{Si}$ ) were also studied in the DSC using a similar procedure.

\section{Results}

\subsection{Differential Scanning Calorimetry Study}
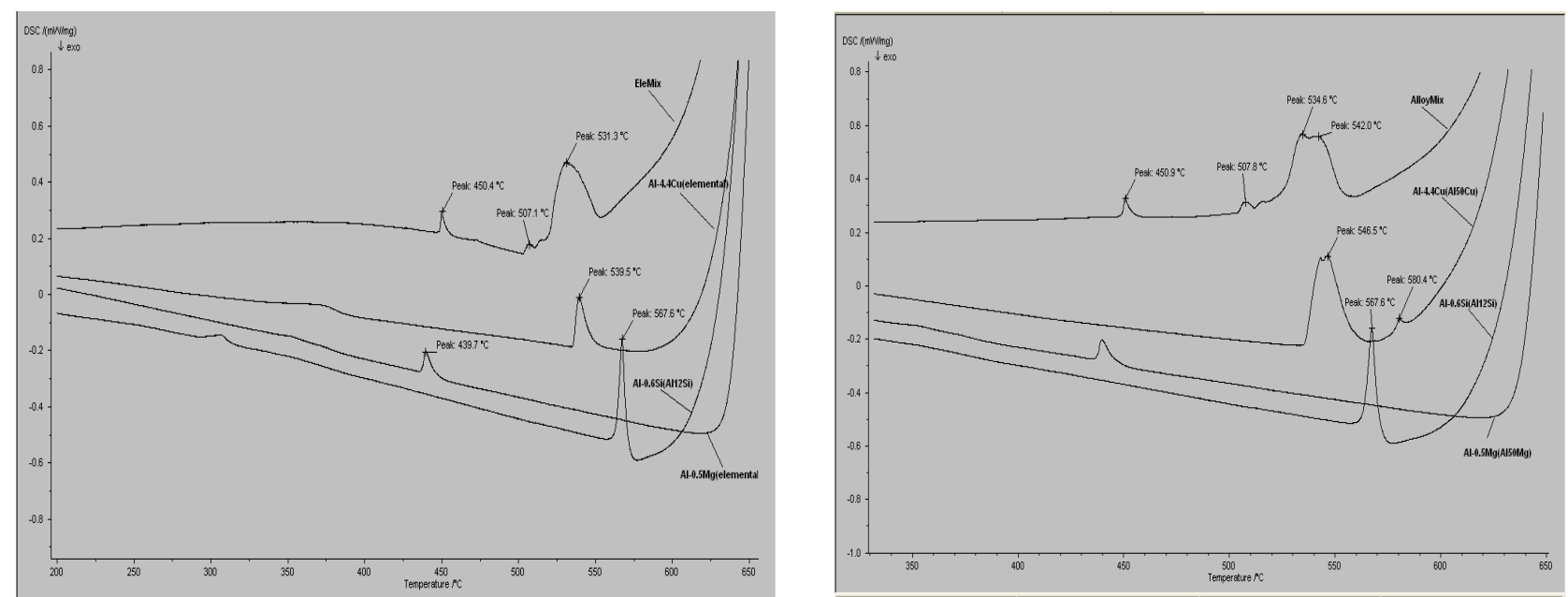

Figure 1. DSC traces of (a) EleMix and (b) AlloyMix Al-Cu-Si-Mg powder blends and Cu, Mg andSi binary combination with Al using elemental (a) and master alloy (b) alloying additions. 
Figures 1(a-b) show typical DSC traces of EleMix and AlloyMix AlCuSiMg powders, respectively together with binary elemental mixture of $\mathrm{Al}-4.4 \mathrm{wt} \% \mathrm{Cu}$, Al- $0.6 \mathrm{wt} \% \mathrm{Si}$ and $\mathrm{Al}-0.5 \mathrm{wt} \% \mathrm{Mg}$ for comparison. For binary $\mathrm{Al}-4.4 \% \mathrm{Cu}, \mathrm{Al}-0.6 \% \mathrm{Si}$ and $\mathrm{Al}-0.5 \% \mathrm{Mg}$ systems prepared using $\mathrm{Al}$ and elemental alloying additions, DSC shows endothermic peaks at about $440^{\circ} \mathrm{C}, 540^{\circ} \mathrm{C}$ and $567^{\circ} \mathrm{C}$ which correspond to the eutectic melting temperature[15] as shown in Fig.1(a). Similar DSC peaks were observed for binary compositions prepared using $\mathrm{Al}$ and master alloy alloying additions. In addition another endothermic peak with an onset temperature around $590{ }^{\circ} \mathrm{C}$, corresponding to the melting of Al-Mg, Al-Cu and Al-Si solid solutions, is observed.

It is believed that interdiffusion between the starting particulate constituents causes the intial formation of eutectic liquid. However, further heating causes more interdiffusion and changes the composition and amounts of the liquid-solid phases (eg. transient aspect). Eventually, all the liquid dissapears and the solid solution remains which melts at a higher temperature. However, this mechanism of phase transformation in binary systems appears to be independent of the type of starting alloying addition (eg. elemental or master alloy).

For the EleMix samples, the DSC trace in figure 1(a) consists of three endothermic peaks at $450{ }^{\circ} \mathrm{C}$, $507^{\circ} \mathrm{C}$ and $530{ }^{\circ} \mathrm{C}$. AlloyMix samples show a very similar DSC trace in Fig $1(\mathrm{~b})$. The $450{ }^{\circ} \mathrm{C}$ peak is believed to correspond to the formation of Al-Mg eutectic liquid. However, the subsequent peaks at higher temperature are believed to be caused by formation of a ternary liquid phase.

\subsection{Microstructural study}

Microstructure of specimens heated up to the critical transformation temperatures indicated by the DSC peaks was evaluated.
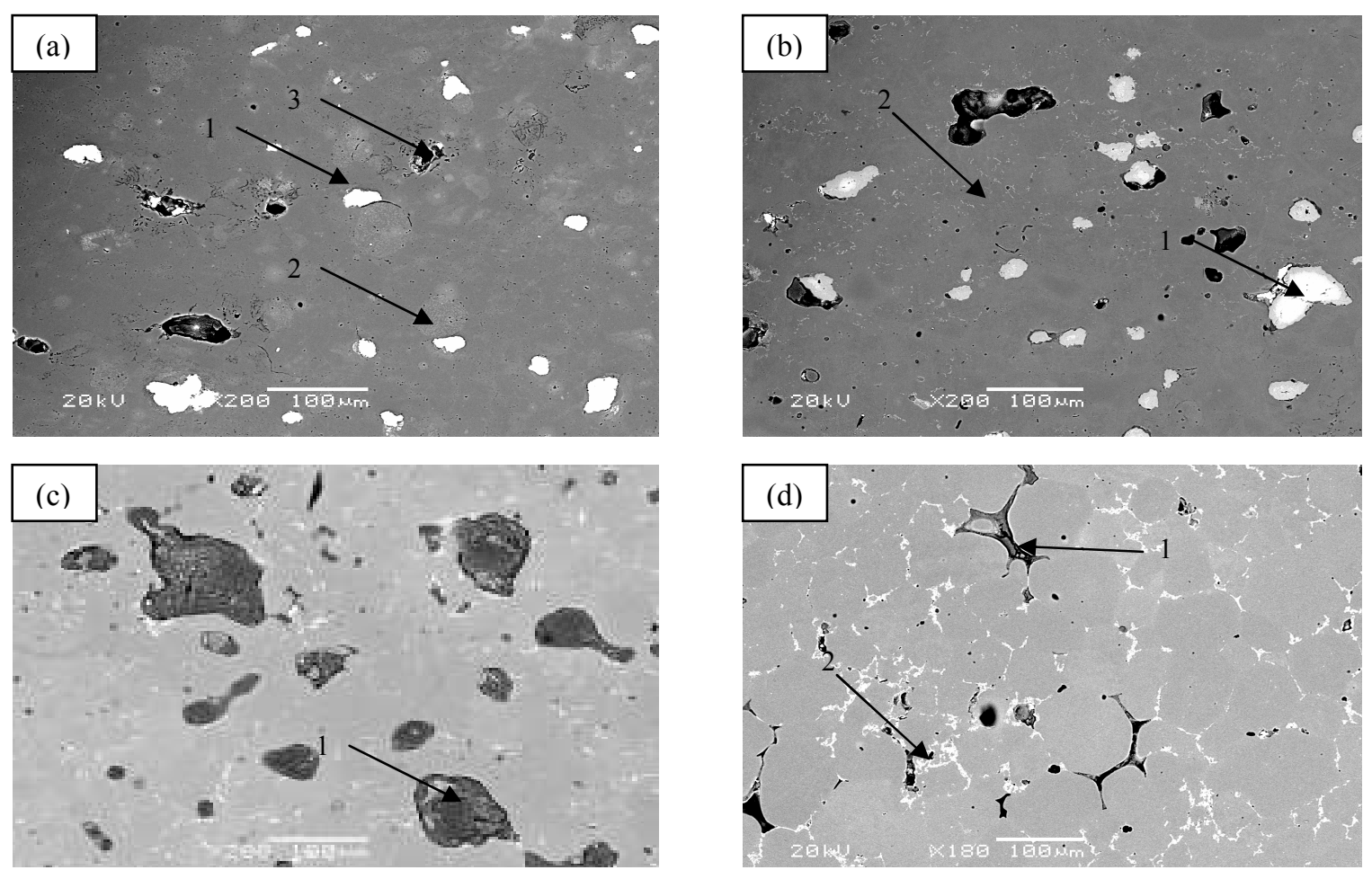

Figure 2 SEM micrographs of AlloyMix Al-Cu-Si-Mg powder blend heated upto (a) $475^{\circ} \mathrm{C}$,

(b) $510^{\circ} \mathrm{C}$, (c) $540^{\circ} \mathrm{C}$ and (d) $600^{\circ} \mathrm{C}$ for 10mins and quenched in liquid nitrogen.

At $475{ }^{\circ} \mathrm{C}$ the microstructure consisted of $\mathrm{Al}$ matrix with undissolved $\mathrm{Cu}$ particles (1), Si rich eutectic regions (2) and pores (3). At $510^{\circ} \mathrm{C}$ the microstructure consisted of Al matrix with large $\mathrm{Cu}$ particles (1) and very fine $\mathrm{Cu}$ precipitates (2) and pores. The region in the vicinity of pores in the 
above cases appeared to be rich in $\mathrm{Mg}$. At $540{ }^{\circ} \mathrm{C}$ the microstructure consisted of large melt pools (1) which have a composition of mainly Al-Si but traces of $\mathrm{Cu}$ and $\mathrm{Mg}$ were found.

At $600{ }^{\circ} \mathrm{C}$ the microstructure consisted of a fully developed $\mathrm{Al}$ grains with a grain boundary phase rich in $\mathrm{Cu}$ and $\mathrm{Si}$ (2). However, remnants of the Al-12\% $\mathrm{Si}$ eutectic liquid can still be observed (1). At temperatures below $540{ }^{\circ} \mathrm{C}$ sintering involves diffusion of $\mathrm{Mg}$ into $\mathrm{Al}$ and formation of $\mathrm{Al}-\mathrm{Mg}$ eutectic liquid. At $540{ }^{\circ} \mathrm{C} \mathrm{Cu}$ formed $\mathrm{Al}-\mathrm{A} 12 \mathrm{Cu}$ structures and $\mathrm{Al}-12 \% \mathrm{Si}$ master alloy eutectic powder turned into liquid. Higher temperature brings the formation of a ternary eutectic liquid located at the $\mathrm{Al}$ grain boundaries.

\section{Conclusion}

- DSC studies suggest the formation of a series of liquid phases (eg. Al-Mg, $\mathrm{Al}-\mathrm{Cu}$ and Al$\mathrm{Si}$ )

- Low sintering temperature involves the diffusion of $\mathrm{Mg}$ and $\mathrm{Cu}$ into the $\mathrm{Al}$ matrix.

- High sintering temperature involves formation of eutectic liquids leading to liquid phase sintering.

\section{Acknowledgement}

The authors would like to thank The Aluminium Powder Company, UK for the supply of the Al powder blends for this study. The authors would like to thank Prof. P. Bowen for the provision of the experimental facilities.

\section{References}

[1] Patrice Delabre and Michael Krehl, Proceedings of the second International P/M and Light Alloys for Automotive Conference, November 2000, p 33

[2] Diran Apelian and Deepak Saha, Proceedings of the second International P/M and Light Alloys for Automotive Conference, November 2000, p 1.

[3] M. A Kearns and J.W Wright, Proceedings of the second International P/M and Light Alloys for Automotive Conference, November 2000, p 93.

[4] "Aluminium P/M: Past, Present and Future", International Journal of Powder Metallurgy, Sept. 2000, p 18

[5] Werner Schatt and K.P Wieters, "Powder Metallurgy- Processing and Materials", Edited by European P/M Association, 1997.

[6] A. Fujiki, Mater. Chem. Phys. 67 (1-3) (2001) 298-306.

[7] M.L Delgado et.al., Journal of Materials processing Technology, 162-163, 280-285, 2005.

[8] G.D Lawrence and G.S Forester, The Dow Chemical Company, Midland Michigan, p 1-12, 1969.

[9] Edul M.Daver and Donald P.Ferris, Modern Developments in Powder Metallurgy, vol.10, p 357, 1977.

[10] J.M. Martin ET AL., Powder Metallurgy, vol.45, No.2, 173-180, 2002.

[11] T.B. Sercombe and G.B. Schaffer, Acta Mater. 47 (1999), pp. 689-697.

[12] T.B. Sercombe and G.B. Schaffer, Mater. Sci. Eng. A2 68 (1999), pp. 32-39.

[13] G.B. Schaffer, T.B. Sercombe and R.N. Lumley, Mater. Chem. Phys. 67 (2001), pp. 85-91.

[14] T.B Sercombe, G.B. Schaffer, Science 301 (2003), pp1225-1227

[15] www.aluminium.matter.org.uk/content/

[16] C.L Falticeanu, ITH Chang, R. Cook, Proceedings of the World Congress in P/M, Vienna, October, 2005. 